\title{
Parents' Value of Play in Early Childhood: A Comparative Study of Spousal Play Beliefs
}

\author{
Meghan C. DeVito \\ West Virginia University
}

Follow this and additional works at: https://researchrepository.wvu.edu/etd

\section{Recommended Citation}

DeVito, Meghan C., "Parents' Value of Play in Early Childhood: A Comparative Study of Spousal Play Beliefs" (2014). Graduate Theses, Dissertations, and Problem Reports. 127.

https://researchrepository.wvu.edu/etd/127

This Thesis is protected by copyright and/or related rights. It has been brought to you by the The Research Repository @ WVU with permission from the rights-holder(s). You are free to use this Thesis in any way that is permitted by the copyright and related rights legislation that applies to your use. For other uses you must obtain permission from the rights-holder(s) directly, unless additional rights are indicated by a Creative Commons license in the record and/ or on the work itself. This Thesis has been accepted for inclusion in WVU Graduate Theses, Dissertations, and Problem Reports collection by an authorized administrator of The Research Repository @ WVU. For more information, please contact researchrepository@mail.wvu.edu. 
Parents' Value of Play in Early Childhood: A Comparative Study of Spousal Play Beliefs

Meghan C. DeVito

Thesis submitted to the

College of Education and Human Services

at West Virginia University

in partial fulfillment of the requirements for the degree of

\author{
Master of Arts \\ In Educational Psychology \\ With an emphasis in \\ Child Development and Family Studies \\ Barbara G. Warash, Ed. D., Chair \\ Amy Kennedy Root, Ph. D. \\ Reagan Curtis, Ph. D. \\ Department of Learning Sciences and Human Development
}

Morgantown, West Virginia

2014

Keywords: play, belief, parent, academics, early childhood

Copyright 2014 Meghan C. DeVito 


\begin{abstract}
Parents' Value of Play in Early Childhood: A Comparative Study of Spousal Play Beliefs Meghan C. DeVito
\end{abstract}

Play is a vital tool for developmental growth and learning in early childhood. However, with the current focus on academics, there is less emphasis placed on encouraging children to play. The current study investigated parental beliefs on play. The sample consisted of 34 middle-class couples (34 mothers, 34 fathers) co-parenting a preschool-aged child (3-5 years) attending the laboratory school of a large mid-Atlantic university. Participants were surveyed about their beliefs on play. Results revealed mothers' value of play to be higher than fathers'. Although significantly different, both mothers and fathers perceived play positively. The findings suggest that early childhood professionals need to further advocate the importance of quality play and its ties with academic achievement to all parents, especially those from lower socioeconomic backgrounds.

Keywords: play, belief, parent, academics, early childhood 


\section{Acknowledgements}

I would like to take the opportunity to express my sincerest gratitude to my advisor and committee chairperson, Dr. Barbara Warash. Her guidance, support, and encouragement has greatly contributed to the attainment of my Master's degree. Her compassion as an advocate and educator for young children has truly been an inspiration to me. Along with my committee chairperson, I would like to thank my fellow committee members, Dr. Amy Root and Dr. Reagan Curtis, as well as Dr. Suzanne Hartman for their assistance throughout the development of my thesis. In addition I would like to thank Keri Law and Melissa Workman for their direction and support throughout my graduate studies. Finally, I would like to thank my family who has never stopped believing in me. Your love and continued support has given me the confidence to succeed in my education and life. 


\section{Table of Contents}

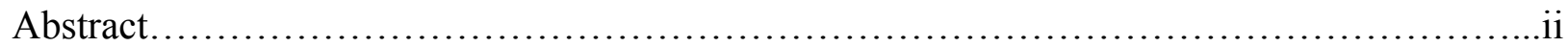

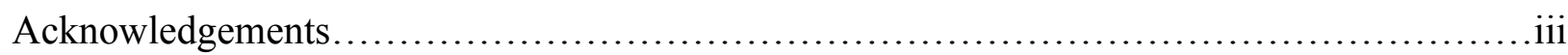

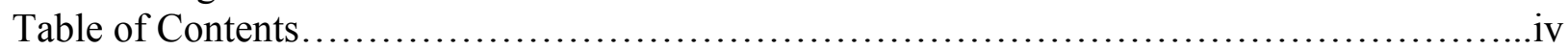

Chapter I

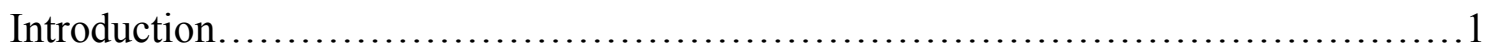

Chapter II

Review of Literature ........................................................4

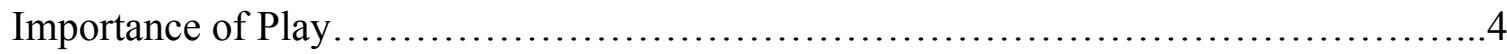

Current Trends in Children's Play ................................................... 8

Parental Play Beliefs........................................................... 11

\section{Chapter III}

Methods...................................................................19

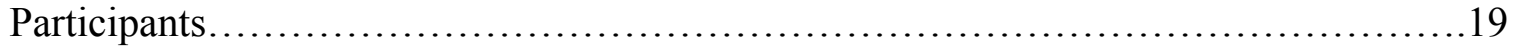

Cross-sectional Survey Design.................................................20

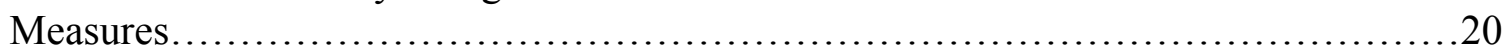

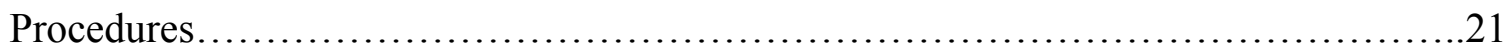

Chapter IV

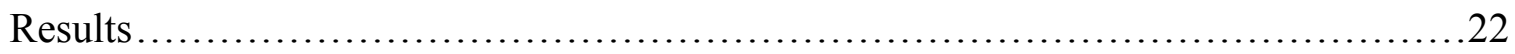

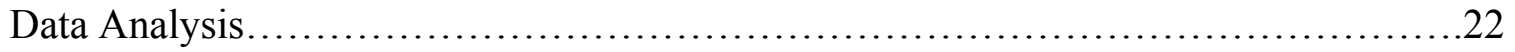

Research question one................................................22

Research question two............................................... 22

\section{Chapter V}

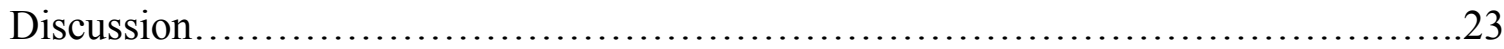

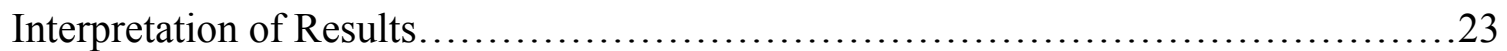

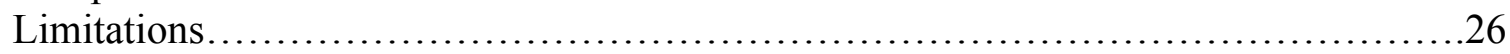

Implications for Future Research............................................27

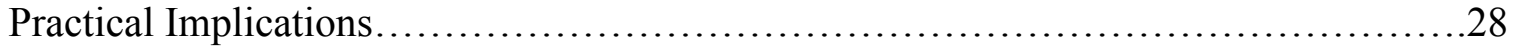

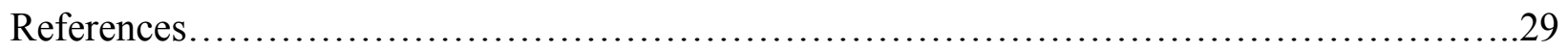

Appendix....................................................................... 33 


\section{Chapter I}

\section{Introduction}

Throughout history play has served as a fundamental component in the learning and development of young children (Fisher, Hirsh-Pasek, Golinkoff, \& Gryfe, 2008; Copple \& Bredekamp, 2009; Van Hoorn, Nourot, Scales, \& Alward, 2011). As an abstract concept, play operates as a multidimensional tool with various forms and purposes, making it difficult to narrowly define. Numerous theorists have established play as the leading contributor to the development and learning of children (Erikson, 1963; Mead, 1934; Copple \& Bredekamp, 2009; Piaget, 1962; Vygotsky, 1978). According to Piaget (1962), children's play develops from simple to complex as well as progresses through stages. From infancy to the school-age years, the progression of an individual's development and play maturation bidirectionally influence each other. During this evolution, children engage in several forms of play including: physical play, object play, constructive play, pretend play and games with rules. Vygotsky believed children behave beyond their age when engaging in make-believe or pretend play (Berk \& Winsler, 1995). In turn, children grasp a better understanding of societal norms and learn to cooperate with others. Not only are these experiences providing children with pivotal learning opportunities but they are significant predictors of children's future academic success (Bodrova \& Leong, 2005; Copple \& Bredekamp, 2009; Sharif, 2009).

It has been suggested that school readiness is not solely based on academics; rather a compilation of the child's physical, social-emotional, language, and cognitive development should be taken into account (National Education Goal Panels, 1997; Copple \& Bredekamp, 2009). The National Association for the Education of Young Child (NAEYC; Copple \& Bredekamp, 2009) has advocated the need for young children to be engaged in developmentally 
appropriate activities that fit the child's level of development (Copple \& Bredekamp, 2009). Developmentally appropriate practice includes play as the major vehicle for learning in the preschool years. There is a 'play-learning' conceptualization in which "play, in its many forms, represents a natural, age-appropriate method for children to explore and learn about themselves and the world around them" (Fisher et al., 2008, p. 306). Other than being 'fun', play is a vehicle for learning and growth in all areas of the child's development.

Contrary to this belief, in today's society, the importance of play has been overshadowed by the emphasis placed on school readiness. Early learning standards for preschoolers have been established in most states, which indicates more structure as well as an increase in accountability. Today's preschool programs are becoming a part of the public school arena, which gives credibility to early childhood programs, however it often places demands for more formal educational practices. This results in the downward escalation of curriculum and often negates the opportunity for young children to engage in play. State standards for preschoolers set precedence that early childhood is important, yet it creates the potential for a more academic atmosphere for young children. More academic pressure in preschool classrooms sends a message to parents on what is valued in our educational system.

Children's play experiences are greatly influenced by their parents' perceptions (Fisher et al., 2008; Sharif, 2009; Shine \& Acosta, 2000). Parental attitudes and beliefs have the ability of enhancing or hindering the quality of their children's play. Parents who value the importance of play are likely to encourage their children's play opportunities. Studies show through observation and imitation children with older playmates tend to engage in mature play (Leong \& Bodrova, 2012). As play facilitators, parents can optimize their children's playtime by becoming 
their children's playmate. However, with the push for more academics do parents value the play of their children and view it as a learning opportunity?

The purpose of this study was to investigate parents' values of play in early childhood including a spousal comparison of play beliefs. This research provides a better understanding of the value placed on play by contemporary parents of young children. 


\section{Chapter II}

\section{Literature Review}

The below literature review substantiates play as a tool for learning in early childhood. Focus was primarily on the usage of the latest findings on play, therefore articles published within the past decade were prioritized. Relevant publications from earlier dates were taken into consideration. Obtained articles were reviewed and organized based on commonalities. Consistent findings throughout articles became critical topics to examine in this review, including: the importance of play, current trends in children's play, and play beliefs of parents with preschool-aged children.

\section{Importance of Play}

Play is arguably one of the most influential forces of development throughout childhood. Friedrich Froebel (1887), the founder of kindergarten, provided one of the first definitions of play stating that, "Play is the highest expression of human development in childhood for it alone is the free expression of what is in a child's soul" (p. 55). Embedded in the constructivist theory is the notion that development during childhood is facilitated through exploration of the social and physical environment as children play (Van Hoorn et al., 2011). Research on brain development shows that experiences in the first five years of life have significant implications on children's development and learning in the future (Gilbert, Harte, \& Patrick, 2011). With the first onsets beginning in infancy, play's presence can be existent into the elementary years. In a fun, yet meaningful manner, play allows children to be explorers in their own environment (Isenberg \& Jalongo, 1997).

There are several renowned theorists who underscore play. Jean Piaget (1962) believed 
play to be one of the most vital functions of childhood, promoting total development. He illustrates three stages of play: functional or sensorimotor play, symbolic play, and games with rules, which align with his three stages of intellectual development. He argued that play helps children move beyond egocentrism so that they can take on others' perspectives and allows children to assimilate and accommodate new information about the world around them. Piaget also believed that, play "bridges the gap between sensory-motor activity prior to representation, and the operational forms of thought" (p. 1).

According to Lev Vygotsky (1967), play largely contributes to several avenues of child development, including children's language, cognitive, and social skills. Vygotsky's definition of play is focused on dramatic play of preschoolers and school-age children. In his opinion, this type of play requires children to plan ahead, take on roles and abide by rules. Vygotsky believed play creates a zone of proximal development, which is a distance from the child's actual level he/she is functioning at to the subsequent level he/she can emerge to through guided problem solving with the help of adults or mature players (Bodrova \& Leong, 2007; Vygotsky, 1967). Unlike Piaget (1962), who believed play is guided by the stages of development, Vygotsky believed development occurs while children engage in play.

Piaget (1962) argued that the first onsets of play begin as early as infancy during the first stage of cognitive development in which he refers to as the sensorimotor period. During this time, engagement in functional play relies on the development of the infant's motor skills. Infants receive stimulation through their caregivers, the environment, and even engaging in play. As mobility increases, they are better able to manipulate objects as well as explore more of their surroundings. Infants begin to engage in goal directed behaviors that become repetitive actions to receive the same response (Piaget, 1962; Van Hoorn et al., 2011). 
According to Piaget (1962), sensorimotor exploration is followed by play and imitation. Infants begin to imitate adult's actions, which become apparent in their play. For instance, after observing parents talking on the telephone, infants will pick up their toy phone and begin to babble in an attempt to imitate their parents' behavior. At the end of the sensorimotor stage, around two years old, children's language progresses with the beginnings of saying simple words (Piaget).

By age two, children are engaging in symbolic play. In the beginnings of this stage, toddlers partake in constructive play and start to represent an object to function as a different object. Piaget's description of the symbolic play stage illustrates how children begin to demonstrate mental representation as a way to use an object to function as something else (Copple \& Bredekamp, 2009; Piaget, 1962; Van Hoorn et al., 2011). Vygotsky also believed that play promoted children's abilities to substitute one object to stand for another, which he describes as "facilitating the separation of thought from actions and objects" (Bodrova \& Leong, 2007, p. 133; Vygotsky, 1967).

Children's play evolves further during this stage, in which they continue to use these props as they engage with others in dramatic play situations. According to Vygotsky, the beginnings of make-believe play, during toddlerhood, is fostered by adults acting as models to demonstrate pretend actions for their toddlers. During this time, children begin to increase their social interactions with others; Bodrova and Leong (2007), Copple and Bredekamp (2009), Mead (1934), Piaget (1962), and Vygotsky (1967) emphasize the importance this has on children's developing awareness of others' perspectives.

During the preschool years, children become increasingly active participants in pretend play. By collaborating with others, children use their imaginations to create make-believe 
scenarios and take on defined roles. Together, children create, what theorist Erik Erikson (1963) described as, their own "microreality", taking on explicit roles, and following implicit rules (Van Hoorn et al., 2011; Vygotsky, 1978). Play partners learn to negotiate these rules as well as construct props suitable for their roles. By learning to self-regulate their impulses and successfully cooperate without relying on adult guidance, children are able to further develop their social-emotional skills (Gilbert et al., 2011). As make-believe play continues to extend and become predominantly child-directed, children participate in high-level play. Vygotsky argued that play supported the development of self-regulation skills by requiring children to control their emotions, increases children's motivation by developing long-term goals, and promotes decentration, in which children learn to take on others' perspectives. This in turn enables children to focus on academic challenges (Bodrova \& Leong, 2007; Vygotsky, 1967).

The final stage of play, games with rules, which is similar to make-believe play requires children to follow clearly defined rules however the roles and imaginary situation are hidden (Bodrova \& Leong, 2007). At this play stage children are able to engage in board games, card games, running games as well as many other games with specific rules. Vygotskians believe playing games with rules prepare children for didactic games, which are playful yet academically enriched games that are commonly used during the school-age years (Bodrova \& Leong, 2007).

Children who are given sufficient playtime during early childhood tend to have later school success (Bodrova, 2012). Several accomplishments during the preschool years have been found to predict school readiness for children including the development of self-regulatory, emotional, social, and cognitive skills (Bodrova \& Leong, 2007). After examining the findings of several studies' investigations on the impact of play, Lillard, Lerner, Hopkins, Dore, Smith, and Palmquist (2012) highlighted that play is one of the essential contributing factors to healthy 
growth and development of young children as well as a predictor of school readiness. Children learn best through "playful learning" (p. 26) rather than sitting through teacher-directed instruction (Lillard et al., 2012).

The evidence reviewed suggests that an underlying factor of pretend play's benefits is its ability to promote positive interactions between adults and children. As a child's play progresses he/she has the ability to engage in mature play which constitutes a higher level of thinking. By encouraging and supporting their child's play engagements, parents have the ability to promote their child's level of play. Parents can expand their child's play repertoire by exposing them to new settings so that they can be familiarized with roles and themes in the environment. In turn, the children will reenact the scenarios through play.

\section{Current Trends in Children's Play}

Historical and modern day research has viewed play as a fundamental asset of early childhood (Fisher et al., 2008). However, the presence of meaningful play activities that facilitates learning is often limited and not always emphasized in preschool setting. It is the didactic approaches that gain the attention of the public.

NAEYC's (Copple \& Bredekamp, 2009) Position Statement emphasizes that:

Play is an important vehicle for developing self-regulation as well as for promoting language, cognition, and social competence... High-level dramatic play produces documented cognitive, social and emotional benefits. However, with children spending more time in adult-directed activities and media use, forms of child play characterized by imagination and rich social interactions seem to be declining... Rather than detracting from academic learning, play appears to 
support the abilities that underlie such learning and thus to promote school success. (pp. 14-15)

Growing misconceptions that early onsets of basic reading skills are indicators of school success have drastically altered children's play (Miller \& Almon, 2009). Elkind (2010) and Fisher et al. (2008) found play in school and home environments has transformed from being child-initiated unstructured play to structured educationally based activities. In 1981, David Elkind first expressed his concern that children were being pushed through childhood with few play opportunities. For over two decades play has been pushed aside or transformed into work for young children. Due to the decline in allotted playtime in early childhood classrooms, it is crucial for parents and teachers to provide children with quality play opportunities during this restricted window of time (Leong \& Bodrova, 2012).

Play opportunities for young students are increasingly sacrificed due to the push for academic excellence in the school setting. Rather than providing optimal learning experiences through play, young children are expected to learn through methods of memorization to meet academic standards (Fisher et al., 2008). However, research shows when compared to nonplayers, children who are given opportunities to engage in quality socio-dramatic play have greater language skills, social skills, self-regulation and think on a higher level (Miller \& Almon, 2009). For instance, children's imaginative play increases their repertoire of roles which has the potential to promote their knowledge and abilities to give meanings to words, known as metalinguistic awareness (Leong \& Bodrova, 2003).

Play has changed in other ways. Children today spend most of their time at home in front of the television or computer screen rather than engaging in outdoor play. Researchers estimated that the average American home with young children has the television on for six hours daily 
(Jordan \& Woodard, 2001). The American Academy of Pediatrics has found a linkage between increased screen time and negative behavioral, psychological, and psychical consequences in children (Fitzgerald, 2011). It is recommended that screen time should be limited to no more than two hours per day for children, however it appears they supersede these limits.

Dr. Elena Bodrova (personal communication, October 3, 2012) claimed, rather than playing outdoors, today's parents are able to keep a close eye on their children by limiting their play to indoors. Outdoor play opportunities for children are limited to parents enrolling them in organized activities that are instructed by adults and consist of only age-related peers.

Learning to play informally within neighborhood groups of multi-age children is a thing of the past. Play skills were once learned from older "play experts" that children could practice with their age-related peers and then pass down their play knowledge to other "play novices" (Leong \& Bodrova, 2012, p. 31). Most children can no longer reap the benefits of playing with older peers. Playing with only same age peers, who have play skills at the same level, does not provide children with a model to engage in higher-level mature play. As a result, children are entering preschool with immature play skills and some are even finishing kindergarten without knowing how to play (Bodrova \& Leong, 2007). The few fortunate children who have childdirected play opportunities involving groups of mixed-age peers have an easier time concentrating and self-regulating (Bodrova \& Leong, 2005). Concentration and self-regulation are two predictors of future academic success, allowing children to focus on learning new skills. Playing with older peers, "play mentors" (p. 6), allows children to promote their cognitive and social skills by imitating more advanced behaviors. Bodrova and Leong (2005), who have studied the effect of mature play, urge parents to avoid sacrificing childhood playtime. 
Quality of play has diminished for other reasons as well. Play today is highly associated with toys whereas in the 19th century play was primarily an activity (Spiegel, 2008). In addition, children's current toys fail to require them to use their imaginations. The temptations of children using technology limits the opportunity for children to engage in quality play. For example, the educational means of electronic toys are falsely advertised to be equivalent to reading a book, however they fail to reap the benefits of reading in a traditional manner (Fisher et al., 2008).

In essence, play has changed over the years. Whether it be the difference in age of playmates, the types of toys, or the reduction in time to play, children are the ones to suffer. However, parents can bring back the pureness of quality play. Play is greatly influenced by parents" beliefs; "children are receptive to parental suggestions and they play in a more sophisticated manner when their parents and caregivers join them" (Sharif, 2009, p. 1). Play provides parents with meaningful opportunities to scaffold their children's learning by socially interacting with their children, which ultimately fosters developmental growth (John et al., 2012). With consideration to the fact that children learn best through play, a natural component of childhood, parents should use play as a tool to promote their children's learning.

\section{Parental Play Beliefs}

Research has found providing children with meaningful play opportunities enriches their early childhood experiences and equips them with the fundamental tools necessary for future academic success (Leong \& Bodrova, 2005; Copple \& Bredekamp, 2009). Parents have the potential to promote their children's growth and development through play yet this depends on their attitudes towards playful learning. With a rich history of notable theorists (Erikson, 1963; Froebel, 1887; Mead, 1934; Piaget, 1962; Vygotsky, 1967) who proclaim the value of play and a growing body of research (Bodrova \& Leong, 2007; Copple \& Bredekamp, 2009) that supports 
learning through play, it is essential to thoroughly investigate how parents today perceive play in early childhood. There are differing perspectives on learning through play. A parent's opinions on his/her child's play as well as his/her involvement may differ from his/her spouse's. Gonzalez-Mena (2008) explains:

One adult may see play as an opportunity for individual involvement with the physical environment, as in self-motivated, solitary play. Another adult my regard plays as an opportunity for learning to get along with others. If solitary play is valued, interruptions by others will be discouraged ... If play is regarded primarily as socialization, the adult will encourage children to interact. (p. 104) Parents' values placed on the importance of play vary due to their conception of what constitutes as meaningful play. To some, structured play that involves more adult guidance may be highly valued whereas others believe unstructured play that is child driven is most beneficial.

Fisher et al. (2008) compared mothers' and professionals' beliefs on play in a two-study analysis. Participants consisted of 1,130 mothers of young children, ages one to five years, in the first study. In the second study there were 99 professionals who were parents as well. Participants in both studies completed a survey, in which they rated a list of play activities in terms of playfulness, their personal frequency of the activity with their child, and the relation activities had to academic learning. Maternal perspectives on the value of play varied, however mothers as well as professionals across the United States unanimously supported playing to learn. It was determined that professionals placed a higher value on unstructured play, whereas many mothers reported structured play to be significantly more important than unstructured play. Mothers' values of play depended on personal beliefs of what constitutes as playful learning. The 
educational value placed on structured and unstructured play by mothers predicted which type of play children primarily engage in at home.

Similarly, Warash, Pelliccioni, and Yoon (2000) compared the views of middle-class parents of preschoolers on developmentally appropriate practice attending the same university preschool program as the participants in the current study. Sixty-four mothers and fathers completed a 20-item survey consisting of statements based on developmentally appropriate practices in early childhood. This included items on play. Parents' reports indicated that mothers support formal teaching methods for their children whereas fathers were found to value a more developmentally appropriate approach to learning. The finding was rationalized by the fact that mothers tend to hold the responsibility of picking their children up from school. Mothers were more likely to see other children's progress at school triggering a competitive instinct to push their children's academic skills. Many parents are likely to overly emphasize school-related skills more so than their children's educators. It should be noted that this is particularly apparent for lower-income parents who believe teaching their children academic skills such as reading and writing to be more important than other valuable behaviors. However the middle class parents in this particular study contradicted this conceptualization. Through verbal communication and the completion of the parent questionnaire on developmentally appropriate practice, mothers thought a more structured learning environment for their children would foster academic success (Warash et al., 2000).

Gleason (2005) investigated mothers' and fathers' beliefs and their involvement in their children's play. Seventy-three mothers and 40 fathers of preschool-aged children completed a parent survey about their feelings on pretend play. Mothers perceived their child's pretend play more favorable than fathers. The differing value placed on play was explained by the fact that 
fathers view play as fun whereas mothers focus on the educational benefits of their preschoolers' pretend play.

John, Halliburton, and Humphrey (2013) investigated the differences in maternal and paternal play interactions with their preschool-aged children. The study's sample consisted of 18 children ranging in age from two to four and a half years old and their two biological parents. When comparing spouses' play beliefs, mothers had a tendency to engage in structured play with their preschooler incorporating academic skills and guiding the child through setting limits. Husbands were more involved in physical play, such as rough and tumble play, with their children. This may be due to the fact that mothers placed an educational value on play whereas fathers perceived these activities as playful interactions (Gleason, 2005; John et al., 2013).

Newland, Coyl, and Freeman (2008) suggest that child attachment security is linked to this type of father-child play in the preschool years. In turn, children with secure attachments to their fathers play at a higher level together (Elkind, 2010). Father-child play is child- navigated involving the father exhibiting child-like behaviors while challenging the child to perform at a higher level (John et al., 2013). Elkind (2010) found that children of fathers with higher educational attainments and incomes benefitted more from their parent-child play experiences.

Parents' beliefs and involvement in play may vary depending on certain characteristics of their child. Mothers and fathers of daughters tend to view pretend play more positively and are more involved in play than those with sons. This may be due to the fact that some parents perceive pretend play as an indoor activity suitable for girls to take on traditional female roles (John et al., 2013; Gleason, 2005). Mothers are more likely than fathers to engage in conversations with their children during play. However, Elkind (2010) found that mothers have more play interactions and conversations with their daughter than with their sons. This maternal 
influence has the ability to promote children's language development. Mothers are generally less likely than fathers to engage in physical play with their children due to the unapparent educational benefits. When they engage in this type of play it tends to be with their sons or laterborn children (Schoppe-Sullivan, Kotila, Jia, Lang, \& Bower, 2013).

Haight, Parke, and Black (1997) utilized a sample of middle class Caucasian husbands and wives who were first time parents to compare their beliefs on pretend play and reading books. Play was compared and contrasted to reading books because they are both thought of as highly verbal activities for children, yet unlike pretend play, reading books is a structured activity. The 22 sets of mothers and fathers of toddlers were all European Americans ranging in age from 25 to 40 years old. Half of all participating mothers and fathers were college graduates with the remaining parents having obtained a high school degree. Findings regarding parental beliefs about pretend play revealed that most parents reported they enjoyed engaging in pretend play with their children, however they preferred reading books with their children. Parents contributed book reading to being a more significant contributor to their children's development and future school success than pretend play. Pretend play was viewed as promoting children's creativity and the conceptualization of social roles and relationships. It was also found that mothers and fathers are unique contributors to their children's development due to the differences in how enjoyable they perceived play activities as well as how significant they viewed their role in their children's play. Maternal roles for this targeted population were held as more traditional as the mother was the primary caregiver. This being said, mothers who perceived pretend play as being important, may have felt a more obligatory responsibility than fathers to participate in their children's play. 
A children's museum in Texas was designed to promote parent-child play in exhibits depicting familiar natural settings. Shine and Acosta (2000) conducted two studies investigating parent-child play interactions in the museum. The first study consisted of 30 parent-child play observations in the grocery store area; parents were unaware of their involvement in the study. The second study at the museum observed 14 parent-child pairs in four exhibit areas. The participants were recruited from local preschools and child care centers; parents were aware of their participation in the study. Both studies consisted of naturalistic observations of the parentchild play interactions. In the second study parents participated in a follow-up interview pertaining to their thoughts on play; these parents acknowledged the importance of learning through play. This being said, rather than engaging in pretend play with their children, parents in both studies spent most of their time teaching about the environments their children were playing in. Jones (2012) points out that although most parents report that they do play with their children, the vast majority are monitoring rather than mentoring. It appears as though parents ideally want to be involved in their children's play but are unaware of the proper way to interact with them in a supportive and beneficial manner. In order to strengthen children's play, parents need to start playing with their children. In regard to pretend play roles, Shine and Acosta found that parents were fixated on teaching their children about a certain role, however "play is not that children learn about specific roles, but that children learn that humans take on roles which correspond to frames of action" (p. 50).

It has been noted that children who have sophisticated play partners, such as their parents, are likely to experience growth in their skill abilities (Sharif, 2009). However, not all parental involvement is beneficial, parents who struggle to see the importance of play have a tendency to negatively disrupt their child's play rather than enhance it. 
Although the study in which the Parent Play Belief Scale (PPBS) was developed used a sample that was significantly different than the current study, it is relevant to review those results for possible similarities. Fogle and Mendez (2006) used a sample of 224 African American mothers of Head Start children. The participating mothers' ages ranged from 19 to 53 years old with children ranging in age from 38 to 67 months. Mother who had high levels of Play Support viewed play as a priority and a mechanism for learning. Mothers who rated Academic Focus as high had a different belief system and valued academic skills as a priority. Because the constructs of Play Support and Academic Focus emerged from the study indicates there are parental differences in the value of play. Parents with higher educational attainments have a tendency to hold more positive and supportive play beliefs, whereas less educated parents have higher academically focused beliefs. Findings in this study confirmed that Play Support is positively associated with parents' educational level whereas Academic Focus is negatively associated to parents' education.

Miller (1989) investigated the socialization of children in terms of the social status of parents. Parents with lower socioeconomic statuses had a tendency to enroll their children in day cares that were predominately teacher-directed and heavily emphasized academics. Parents of middle class status or professional standings typically enrolled their children in centers that were primarily child-driven programs that facilitate the independence and creativity of young children. The socioeconomic statuses of parents influences their parenting values and practices as well as their parenting goals for their children. Parents from lower socioeconomic backgrounds value instilling obedience and conformity in their children, whereas parents from higher socioeconomic backgrounds emphasize the promotion of self-confidence and self-direction of their children (Leyendecker, Harwood, Comparini \& Yalcinkaya, 2005). These varying parental 
values based on socioeconomic status may account for their differences in preferences of their children's educational settings.

To summarize, play is the primary vehicle for young children's social, emotional, cognitive and physical development. However, with the current national efforts to provide more academic programs such as universal pre-k comes the possibility of more didactic teaching methods. School systems are mandated to report their progress on standardized measures. This factor alone sends the public a message that skill development is a priority. Play is not one of the items measured nor is it one that teachers usually report to parents. With that said, the following research questions guided the study: 1) Do parents value and support play as measured on the “Parent Play Belief Scale?” 2) Is there a difference in mothers' and fathers' overall play beliefs as measured on the "Parent Play Belief Scale?" 


\section{Chapter III}

\section{Method}

\section{Participants}

The sample for this study was selected from the population of 38 sets of mothers and fathers of children attending the West Virginia University Nursery School in Morgantown, West Virginia. The Nursery School serves as a laboratory school for students completing their requirements for certification in child development/early childhood. The Nursery School follows the guidelines of the National Association for the Education of Young Children. Therefore, play is emphasized and used as a vehicle for children's learning. There is a waiting list of three years for admittance to the preschool. Parents seeking enrollment for their children place their children on that list at birth. At the time of the data collection, all parental participants were co-parenting their preschool-aged child with their participating spouse. A total of 68 parents (34 mothers, 34 fathers) voluntarily participated in this study. The average age for the maternal participants ranged in age from 31-40 years old. The average age for the paternal participants ranged in age from 36-40 years old. The director of the school reported that the majority of participants were from a higher socioeconomic background. Approximately $71 \%$ of parents obtained a standard college or university bachelor's degree or higher. The estimated $29 \%$ of parents without a degree had some type of specialized training or partially completed college (at least one year). Of the 68 children of the participating parents, 29 were females and 39 were males. The average child's age was 51.82 months $(S D=8.29)$.

\section{Cross-sectional Survey Design}


The design used in this study was the cross-sectional survey design. This design was selected because it provided insight to parents' perspectives of play while their child is preschool-aged. Participation in this study was voluntary. By having an approximate $80 \%$ response rate, the findings in this study are highly generalizable to the target population, taking into account the educational attainment level of the sample.

\section{Measures}

An adapted version of the Parent Play Belief Scale (PPBS) (see Appendix) developed by Fogle and Mendez (2006) was distributed to each parent to complete. The questionnaire consisted of five-point Likert Scale items ranging from Strongly Disagree to Strongly Agree addressing parents' beliefs about their preschool children's play. The PPBS was designed as a measurement tool to examine the multidimensional avenues of African American parents' play beliefs including "developmental significance of play, participation in play, enjoyment of play" as well as "perspectives on play and pre-academic activities" (Fogle \& Mendez, 2006, p. 509). The participants of Fogle and Mendez's (2006) study were all African American mothers whose children were enrolled in Head Start programs. The 30-item pilot version of the measure had a coefficient alpha of .86, indicating good internal consistency. All items from the piloted questionnaire were included in Fogle and Mendez's (2006) study which determined two significant factor loadings: Play Support, consisting of 17 items such as "playing at home will help my child get ready for kindergarten," and Academic Focus, containing 8 items with statements including "I do not think my child learns important skills by play." The Play Support subscale had a Cronbach's alpha coefficient of .90 and the Academic Focus subscale had a Cronbach's alpha coefficient of .73, demonstrating adequate reliability. 
The 25 items under the two subscales, Play Support and Academic Focus, were retained for use in the current study with an additional four questions that were structured by two experts in the field of child development. These items included statements regarding outdoor play, parents' history of play, and the use of technology for educational purposes. These four items' findings will be retained for future research studies. When first computing the statistical analysis, the Play Support subscale had a Cronbach's alpha of .902 and the Academic Focus subscale had a Cronbach's alpha coefficient of .705. In order to improve the alpha for Academic Focus, items 19 and 20 regarding reading were removed resulting in a Cronbach's alpha coefficient of .802.

\section{Procedures}

One packet consisting of two surveys, both marked with the same number, and a cover letter providing general information about the study were hand delivered to one parent of each child attending the West Virginia University Nursery School. If both the mother and father of each child volunteered to participate, they completed the survey at home, independently. Upon completion, one of the parents returned the couple of completed surveys back to Nursery School.

The number coding was used to maintain anonymity while allowing researchers to compare spousal perspectives. After a week, a reminder letter was sent home to all parents about completing the survey. The return rate was approximately $80 \%$. If parental participation were low, additional surveys would be sent to parents of the children enrolled in the program for the upcoming school year. The procedure was approved by the university’s Institutional Review Board as a part of a broader study. 


\section{Chapter IV}

\section{Results}

\section{Data Analysis}

Descriptive statistics were computed for all variables and are displayed in Table 1 . The PPBS rating scale indicated parents' overall score for Play Support and Academic Focus.

Table 1

Descriptive Statistics for Mean and Standard Deviation for Parent Play Belief Scale

\begin{tabular}{|c|c|c|c|c|c|c|}
\hline \multirow[b]{2}{*}{ Variable } & \multicolumn{2}{|c|}{ Total } & \multicolumn{2}{|c|}{ Fathers } & \multicolumn{2}{|c|}{ Mothers } \\
\hline & $M$ & $S D$ & $M$ & $S D$ & $M$ & $S D$ \\
\hline Play Support & 4.60 & 0.38 & 4.53 & 0.42 & 4.67 & 0.32 \\
\hline Academic Focus & 1.31 & 0.36 & 1.42 & 0.35 & 1.20 & 0.34 \\
\hline
\end{tabular}

Research question one. The results from PPBS rating scale indicated parents' mean item response for Play Support was 4.6 $(S D=0.38)$, and for Academic Focus was $1.31(S D=0.36)$. Item ratings ranged from 1 to 5 indicating a Play Support mean score higher than the mid point and an Academic Focus mean score lower than the mid point.

Research question two. A correlation exists within spousal dyads for both Play Support $(r=.13)$ and Academic Focus $(r=.32)$ therefore, to address the hypotheses regarding how parents' beliefs on play differ between mothers and fathers, the means of mothers' and fathers' scores were compared by conducting a $t$ test for dependent samples (alpha $=.05)$. 
Results indicated that fathers placed a higher value on Academic Focus $(M=1.42, S E=$ $.06)$ than mothers $(M=1.20, S E=.06), t(33)=3.92, p<.004$. In addition, mothers placed a higher value on Play Support $(M=4.67, S E=.05)$ than fathers $(M=4.53, S E=.07), t(33)=-$ $2.23, p<.005$. 



\section{Chapter V}

\section{Discussion}

\section{Interpretation of Results}

This study investigated parents' beliefs regarding their preschool children's play. In addition, the perspectives of mothers and fathers were compared. The PPBS was used to assess parents' overall value of play as well as two aspects of parents' play beliefs: Play Support and Academic Focus. The Play Support items collected "parents' positive beliefs about the developmental significance of play and their own involvement in children's play.... Academic Focus included items which reflect an emphasis on academic skills, such as learning numbers or letters, and a belief that play does not have a central role in facilitating the development of these skills" (Fogle \& Mendez, 2006, p. 515). The following research questions guided the study: 1) Do parents value and support play as measured on the "Parent Play Belief Scale?" 2) Is there a difference in mothers' and fathers' overall play beliefs as measured on the "Parent Play Belief Scale?"

In response to the first research question, parents in this study valued play. Scores on the subscale of Play Support were higher than the subscale of Academic Focus on the PPBS. In fact, the mean item response for Play Support was 4.6 out of a possible 5 and for Academic Focus it was 1.3 out of a total 5 . This indicates that parents in this study value play for their children and value their own involvement in that play. This was not a surprising result considering the participant's educational and occupational levels. Most of these middle class parents have professional occupations and college degrees. These parents chose a preschool with a prominent view on play as is stated on the school's website and other promotional materials. It would be 
expected that parents who want their children to attend this preschool would value the philosophical undertone that "play" has in the curriculum. It would seem that parents who value this type of educational setting would also value its curriculum that is highly play oriented. However, with the emphasis on academics and accountability in preschool programs and the national importance placed on universal pre-k, it cannot be assumed that middle class parents or any parent feels this way. Newspapers are bombarded with information on such issues as teaching to the test and limiting recess so children have more academic time. This finding on the value of play by middle class parent is similar to the research of Miller (1989) who found that parents from middle class and/or professional backgrounds seek child directed centers where the focus is on creativity. Conversely, parents in low status occupations place a heavier emphasis on academics. These parents tend to value more teacher directed academically oriented schools when seeking one for their children (Miller, 1989).

Fogle and Mendez (2006), the authors of the PPBS, used a sample of African American mothers with children enrolled in Head Start. Head Start is a program with income restrictions, requiring that parents meet the federal guidelines for low income unless they have a child with special needs that qualifies for services. It is a federal program that offers comprehensive services to children and families. These mothers also valued play support but not to the extent of the sample in this study. Head Start is known for its parent component and family support which may have influenced this finding in the study.

Although, it can be generally stated that parents in the current study support play, it was mothers who placed a higher value on the subscale of Play Support. Fathers placed a higher value on academics than mothers. This finding suggests that there is a difference in the play beliefs of mothers and fathers. Fogle and Mendez (2006) had similar results in their study with 
mothers prioritizing play and perceiving play as a learning opportunity for their children. This is not to misconstrue the findings in the current study to say that fathers do not value play but rather to report that mothers had higher scores for Play Support than fathers. Contemplating this finding requires looking at the type of play that mothers often do with their children. Gleason (2005) also found that mothers were more involved in children's play. He found that pretend play was perceived as the more favorable type of play by mothers. This may explain why mothers' beliefs were higher on Play Support; they are often the ones to engage in more pretend play. Ironically, pretend play is the type of play that is so strongly supportive of self-regulation and executive functions, which are needed for the acquisition of academic skills (Bodrova \& Leong, 2007). The current study's findings reflect those of Fisher et al. (2008) who compared spousal perspectives of the importance of play in early childhood. Mothers tended to have a more positive outlook on play than fathers. Is this because mothers are often still in the primary caretaker role and are often the ones observing classroom practices? Mothers are often the ones who bring the child to school and pick the child up from school. Are they the ones who use pick up time as a mechanism to learn about the school environment and the types of developmentally appropriate activities that are beneficial to young children?

Fathers in this study reported higher scores on Academic Focus than mothers. This finding suggests fathers may prefer methods of promoting developmental skills through structured activities more than mothers. They look at preschool as a place to learn numbers and letters using a didactic approach to teaching rather than incorporating it into play. In contrast, mothers value learning through play. Again, this could be due to the involvement of mothers in their child's school whether it is through observations or actual parent involvement activities. It 
may also be due to the fact that father-child play interactions are typically characterized by physical play, which promotes motor skills rather than scholastics (John et al., 2013).

In 2000, Warash, Pelliccionni, and Yoon conducted a study on developmentally appropriate practice, which included opinions on play, produced slightly different results. This study was conducted at the same school. Parents valued play on the survey but there was a difference in mothers' and fathers' beliefs regarding developmentally appropriate practice in early childhood. Fathers appeared to value developmentally appropriate practice for their children's learning compared to mothers who pushed for a more academically structured learning environment. This is an interesting turnabout in 13 years. Although the questionnaire was different than the PPBS, it still had items addressing parents' value of play and didactic teaching encumbered in the questionnaire.

One last note to consider is in order to improve the reliability of the current study's Academic Focus subscale, items 19 and 20 regarding reading were removed. Item 19 states, "reading to my child is more worthwhile than playing with him or her" and item 20 states, "I would rather read to my child than play together." These items were not as closely related to the other Academic Focus items. When investigating items 19 and 20 as a reading subscale, both mothers' and fathers' mean item scores for the couple of reading items was approximately 3 out of 5. This finding suggests that parents may perceive reading as the significant indicator of their children's academic skills. Literacy has been an educational focus of public school for several years.

\section{Limitations}

Parents in this study completed the PPBS at home and could have compared answers with their spouses. This may have influenced participants to change answers to reflect similar 
responses. As mentioned before, parents in this study were highly educated. It would not be difficult for these parents to figure out the intent of the study and answer accordingly. In addition, the participants enrolled their children in an early childhood facility that is advertised as a play enriched environment. This may pose as a limitation towards the generalizability of this study because these parents may have valued play more than the general population of parents with preschool-aged children. The majority of participating parents in the current study had relatively high educational attainments; their awareness of the importance of play in early childhood may have been heightened due to their educational background.

\section{Implications for Future Research}

Findings of this study suggest that parents value play but mothers and fathers differ in their play beliefs. Future research should focus on how parents' play beliefs are linked to their children's behavior. Specifically, do children play differently due to their parents' beliefs regarding their play? Further investigations should aim to explore how parents interact as play partners with their children in natural settings as well as the amount of playtime their child is allotted at home. Data collected from these naturalistic observations can be comparative among mothers and fathers. In addition, conducting a longitudinal study would allow researchers to examine if mothers' and fathers' play beliefs flip or change as their child ages. As their children enter the school-age years, do parents' beliefs regarding their children's play shift?

Examining gender in regard to parental beliefs would also be an important aspect to play research. Research should continue to aim at informing and investigating the importance of play in early childhood in order to encourage caregivers and parents of all socioeconomic levels to provide young children with meaningful play experiences.

\section{Practical Implications}


With the thrust towards universal pre-k, we do not know all the ramifications of the upcoming push for academic instruction for young children. This study found middle class parents valued play but this is not the case for all parents. This means that early childhood educators must continue to advocate for young children to have the opportunity to be in educational environments that are conducive to the way children learn. This message needs to be reiterated and stressed to diverse populations. All children deserve the right to learn in a risk free environment that is embedded with rich play opportunities. The value of play as a tool for learning must be stressed to all parents. 


\section{References}

Berk, L. E., \& Winsler, A. (1995). Scaffolding children's learning: Vygotsky and early childhood education. Washington, DC: National Association for the Education of Young Children.

Bodrova, E., \& Leong, D. J. (2005). Why children need play. Early Childhood Today, 20(1), 6 .

Bodrova, E., \& Leong, D. J. (2007). Tools of the mind: The Vygotskian approach to early childhood education. Upper Saddle River, NJ: Pearson Prentice Hall.

Bodrova, E. personal communication, October 3, 2012.

Copple, C., \& Bredekamp, S. (Eds.). (2009). Developmentally appropriate practice in early childhood programs serving children from birth through age 8. Washington, DC: National Association for the Education of Young Children.

Elkind, D. (2010). Play. In Washington, V., \& Andrews, J.D. (Eds.), Children of 2020: Creating a better tomorrow (85-89). Washington, DC: the Council for Professional Recognition.

Erikson, E. H. (1963). Childhood and Society (2nd ed.). New York: Norton.

Fisher, K. R., Hirsh-Pasek, K., Golinkoff, R. M., \& Gryfe, S. G. (2008). Conceptual split? Parents' and experts' perceptions of play in the 21 st century.Journal of Applied Developmental Psychology, 29, 305- 316.

Fitzgerald, J. (2011). Child's play: Should preschoolers engage with technology or good-old fashioned fun?. [Preschool Matters ... Today] New Brunswick, NJ: National Institute for Early Education Research. Retrieved from http://preschoolmatters.org/2011/06/30/child's-play-should-preschoolers-engage-withtechnology-or-good-old-fashioned-fun/ 
Fogle, L. M., \& Mendez, J. L. (2006). Assessing the play beliefs of African American mothers with preschool children. Early Childhood Research Quarterly, 21, 507-518.

Froebel, F. (1887). The education of man. (W.N. Hailmann, Trans.). New York: Appleton.

Gilbert, J. L., Harte, H. A., \& Patrick, C. (2011). Purposeful play leads to school readiness. Dimensions of Early Childhood, 39, 29-37.

Gleason, T. R. (2005). Mothers' and fathers' attitudes regarding pretend play in the context of imaginary companions and of child gender. Merrill-Palmer Quarterly, 51(4), 412-436.

Gonzalez-Mena, J. (2008). Diversity in early care and education: Honoring differences (5th ed.). Washington, DC: McGraw-Hill

Haight, W. L., Parke, R. D., \& Black, J. E. (1997). Mothers' and fathers' beliefs about and spontaneous participation in their toddlers' pretend play. Merrill-Palmer Quarterly, 43(2), 271-290.

Isenberg, J. P., \& Jalongo, M.R. (1997). Creative expression and play in early childhood. $\left(2^{\text {nd }}\right.$ ed.). Upper Saddle River, NJ: Prentice Hall.

John, A., Halliburton, A., \& Humphrey, J. (2013). Child-mother and child-father play interaction patterns with preschoolers. Early Child Development and Care, 183(3-4), 483-497.

Jones, R. B. (2012). For parents particularly: Playing with your child. Childhood Education, 80(5), 272.

Jordan, A. B., \& Woodard, E. H. (2001). Electronic childhood: The availability and use of household media by 2- to 3-year olds. Zero to Three, 22(2), 4-9.

Leong, D. J., \& Bodrova, E. (2003). Playing to learn. Scholastic Parent \& Child, 11(2), 
28.

Leong, D. J., \& Bodrova, E. (2012). Assessing and scaffolding make-believe play. National Association for the Education of Young Children, 67, 28-34.

Leyendecker, B., Harwood, R. L., Comparini, L., \& Yalcinkaya, A. (2007). Socioeconomic status, ethnicity, and parenting. In T. Luster, \& L. Okagaki (eds.), Parenting: An ecological persepective (319-341). Mahwah, New Jersey: Lawrence Erlbaum Associates.

Lillard, A. S., Lerner, M. D., Hopkins, E. J., Dore, R. A., Smith, E. D., \& Palmquist, C. M. (2013, January). The impact of pretend play on children's development: A review of the evidence. Psychological Bulletin, 139(1), 1-34.

Mead, G. H. (1934). Mind, self and society. Chicago, IL: University of Chicago Press.

Miller, D. F. (1989). First steps towards cultural difference: Socialization in infant/toddler daycare. Washington, DC: Child Welfare League of America.

Miller, E., \& Almon, J. (2009). Crisis in the kindergarten: Why children need to play in school. College Park, MD: Alliance for Childhood.

National Education Goals Panel. (1997). The national education goals report: Building a nation of learners. Washington, DC: U.S. Government Printing Office.

Newland, L. A., Coyl, D. D., \& Freeman, H. (2008). Predicting preschoolers' attachment security from fathers' involvement internal working models, and use of social support. Early Childhood and Care, 178, 785-801.

Piaget, J. (1962). Play, dreams, and imitation in childhood. New York: Garland.

Schoppe-Sullivan, S.J., Kotila, L.E., Jia, R., Lang, S. N., \& Bower, D. J. (2013). Comparison levels and predictors of mothers' and fathers' engagement with their preschool-aged children. Early Child Development and Care, 183(3-4), 498-514. 
Sharif, S. (2009). Parents perceptions of play for child development and learning. Retrieved from http://www.arnec.net/cos/o.x?ptid=1036089\&c=/swt_arnec/ articles $\&$ func $=$ view $\&$ rid $=136$

Shine, S., \& Acosta, T. Y. (2000). Parent-child social play in a children's museum. Family Relations, 49(1), 45-52.

Spiegel, A. (2008). Old-fashioned play builds serious skills. National Public Radio. Retrieved from http://www.npr.org/templates/story/story.php?storyId=19212514

Van Hoorn, J., Nourot, P. M., Scales, B., \&Alward, K.R. (2011). Play at the center of the curriculum (5th ed.). Upper Saddle River, NJ: Pearson Education.

Vygotsky, L. S. (1967). Play and its role in the mental development of the child. Soviet Psychology, 5, 6-18.

Vygotsky, L. S. (1978) Mind in society: The development of higher mental processes. Cambridge, MA: Harvard University Press.

Warash, B. G., Pelliccionni, M. W., \& Yoon, D. P. (2000). The views of middle-class parents on developmentally appropriate practice. Journal of Leadership Quest, 4(2), 8-11. 
Appendix

Parent Play Belief Scale 


\section{PARENT SURVEY}

Your child's age (in months):

Your child is: male female

Your age: 14-17 18-25 $26-30$ $31-35$ $41-45$ $46+$

Your gender:

Your relationship to your child: parent grandparent guardian

How strongly do you agree with the following statements?

\begin{tabular}{|c|c|c|c|c|c|}
\hline & $\begin{array}{c}\text { Strongly } \\
\text { Agree }\end{array}$ & Agree & Indifferent & Disagree & $\begin{array}{l}\text { Strongly } \\
\text { Disagree }\end{array}$ \\
\hline $\begin{array}{l}\text { I believe that children thrive in a home where there } \\
\text { is structure, boundaries, routines, firm discipline, and } \\
\text { non-negotiable well-defined parental rules. }\end{array}$ & 5 & 4 & 3 & 2 & 1 \\
\hline $\begin{array}{l}\text { I bolieve that children should be in a relaxed and } \\
\text { flexibie environment in which children are involved in } \\
\text { family decisions and where boundaries are } \\
\text { negotiated. }\end{array}$ & 5 & 4 & 3 & 2 & 1 \\
\hline $\begin{array}{l}\text { I believe that major decisions should be left up to } \\
\text { parents but while seeking and taking into account } \\
\text { children's input. }\end{array}$ & 5 & 4 & 3 & 2 & 1 \\
\hline
\end{tabular}

How strongly do you believe your spouse would agree with these statements?

\begin{tabular}{|c|c|c|c|c|c|}
\hline 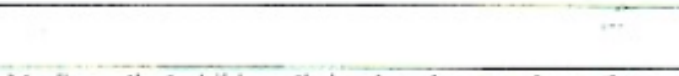 & $\begin{array}{l}\text { Strongly } \\
\text { Agree }\end{array}$ & Agree & Indifferent & Disagree & $\begin{array}{l}\text { Strongly } \\
\text { Disagree }\end{array}$ \\
\hline $\begin{array}{l}\text { I believe that children thrive in a home where there } \\
\text { is structure, boundaries, routines, firm discipline. } \\
\text { and non-negotiable woll-defined parental rules. }\end{array}$ & 5 & 4 & 3 & 2 & 1 \\
\hline $\begin{array}{l}\text { I believo that children should be in a relaxed and } \\
\text { flexible environment in which children are involved } \\
\text { in family decisions and where boundaries are } \\
\text { negotiated. }\end{array}$ & 5 & 4 & 3 & 2 & 1 \\
\hline $\begin{array}{l}\text { I believe that major decisions should be left up to } \\
\text { parents but while seeking and taking into account } \\
\text { children's input. }\end{array}$ & $\therefore$ & 4 & 3 & 2 & 1 \\
\hline
\end{tabular}

With your child, how often do you say "no" in the course of a day?

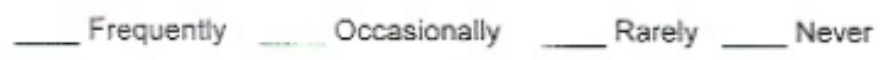

When you say no, if you child is not compliant do you ever negotiate with your child? yes no

If yes, how often:

Always Often or Frequently Occasionally Rarely Never 


\begin{tabular}{|c|c|c|c|c|c|}
\hline & $\begin{array}{l}\text { Strongly } \\
\text { Agree }\end{array}$ & Agree & Indifferent & Disagree & $\begin{array}{l}\text { Strongly } \\
\text { Disagree }\end{array}$ \\
\hline $\begin{array}{l}\text { Play can help my child develop better thinking } \\
\text { abilities. }\end{array}$ & 5 & 4 & 3 & 2 & 1 \\
\hline $\begin{array}{l}\text { Playing at home will help my child get ready for } \\
\text { kindergarten. }\end{array}$ & 5 & 4 & 3 & 2 & 1 \\
\hline I teach my child social skills during play. & 5 & 4 & 3 & 2 & 1 \\
\hline $\begin{array}{l}\text { If I take time to play with my child, s/he will be } \\
\text { better at playing with others. }\end{array}$ & 5 & 4 & 3 & 2 & 1 \\
\hline $\begin{array}{l}\text { Through play, my child dovelops new skills and } \\
\text { abilities. }\end{array}$ & 5 & 4 & 3 & 2 & 1 \\
\hline $\begin{array}{l}\text { Playing at school will help my child get ready for } \\
\text { kindergarten. }\end{array}$ & 5 & 4 & 3 & 2 & 1 \\
\hline $\begin{array}{l}\text { Play helps my child learn to express his or her } \\
\text { feclings. }\end{array}$ & 5 & 4 & 3 & 2 & 1 \\
\hline $\begin{array}{l}\text { Play can improve my child's language and } \\
\text { communication abilities. }\end{array}$ & 5 & 4 & 3 & 2 & 1 \\
\hline $\begin{array}{l}\text { I can help my child learn to control his or her } \\
\text { emotions during play. }\end{array}$ & 5 & 4 & 3 & 2 & 1 \\
\hline Play can help my child develop social skills. & 5 & 4 & 3 & 2 & 1 \\
\hline $\begin{array}{l}\text { Playing together helps me build a good } \\
\text { relationship with my child. }\end{array}$ & 5 & 4 & 3 & 2 & 1 \\
\hline $\begin{array}{l}\text { Playing with my child is one of my favorite things } \\
\text { to do. }\end{array}$ & 5 & 4 & 3 & 2 & 1 \\
\hline $\begin{array}{l}\text { I have a lot of fun with my child when we play } \\
\text { together. }\end{array}$ & 5 & 4 & 3 & 2 & 1 \\
\hline Play is a fun activity for my child. & 5 & 4 & 3 & 2 & 1 \\
\hline My child has a lot of fun when we play together. & 5 & 4 & 3 & 2 & 1 \\
\hline $\begin{array}{l}\text { My child will get more out of play if I play with } \\
\text { him or her. }\end{array}$ & 5 & 4 & 3 & 2 & 1 \\
\hline $\begin{array}{l}\text { It is important for me to participate in play with } \\
\text { my child. }\end{array}$ & 5 & 4 & 3 & 2 & 1 \\
\hline $\begin{array}{l}\text { I do not think my child learns important skills by } \\
\text { playing. }\end{array}$ & 5 & 4 & 3 & 2 & 1 \\
\hline $\begin{array}{l}\text { Reading to my child is more worthwhile than } \\
\text { playing with hirm or her. }\end{array}$ & 5 & 4 & 3 & 2 & 1 \\
\hline $\begin{array}{l}\text { I would rather read to my child than play } \\
\text { together. }\end{array}$ & 5 & 4 & 3 & 2 & 1 \\
\hline Playtime is nol a high priority in my home. & 5 & 4 & 3 & 2 & 1 \\
\hline $\begin{array}{l}\text { Play does not influence my child's ability to solve } \\
\text { problems. }\end{array}$ & 5 & 4 & 3 & 2 & 1 \\
\hline $\begin{array}{l}\text { It is more important for my child to have good } \\
\text { academic skills than to play well with others. }\end{array}$ & 5 & 4 & 3 & 2 & 1 \\
\hline $\begin{array}{l}\text { I do not think it is important for other family } \\
\text { members to play with my child. }\end{array}$ & 5 & 4 & 3 & 2 & 1 \\
\hline $\begin{array}{l}\text { Play does not help my child learn academic } \\
\text { skills. }\end{array}$ & 5 & 4 & 3 & 2 & 1 \\
\hline $\begin{array}{l}\text { My parents encouraged me to go outside and } \\
\text { play. }\end{array}$ & 5 & 4 & 3 & 2 & 1 \\
\hline J encourage my child to go outside to play. & 5 & 4 & 3 & 2 & 1 \\
\hline I feel like my parents valued play. & 5 & 4 & 3 & 2 & 1 \\
\hline $\begin{array}{l}\text { I think letting my child play computer games or } \\
\text { other electronic gamos is helpful to their } \\
\text { educational future. }\end{array}$ & 5 & 4 & 3 & 2 & 1 \\
\hline
\end{tabular}

